CHEMICAL SEPARATIONS PROCESSES

FOR PLUTONIUM AND URANIUM

(TID-4500, 16th Ed.)

\title{
ELECTROLYTIC DISSOLUTION OF POWER REACTOR FUELS IN NITRIC ACID
}

$$
\text { by }
$$

\author{
A. Thomas Clark, Jr., Leon H. Meyer, J. Harding Owen, \\ and Francis G. Rust \\ October 1961
}

E. I. du Pont de Nemours \& Co.

Explosives Department - Atomic Energy Division

Technical Division - Savannah River Laboratory

Printed for

The United States Atomic Energy Commission

Contract $\mathrm{AT}(07-2)-1$

Approved by

W. E. Winsche, Research Manager

Separations Engineering Division 


\section{DISCLAIMER}

This report was prepared as an account of work sponsored by an agency of the United States Government. Neither the United States Government nor any agency Thereof, nor any of their employees, makes any warranty, express or implied, or assumes any legal liability or responsibility for the accuracy, completeness, or usefulness of any information, apparatus, product, or process disclosed, or represents that its use would not infringe privately owned rights. Reference herein to any specific commercial product, process, or service by trade name, trademark, manufacturer, or otherwise does not necessarily constitute or imply its endorsement, recommendation, or favoring by the United States Government or any agency thereof. The views and opinions of authors expressed herein do not necessarily state or reflect those of the United States Government or any agency thereof. 


\section{DISCLAIMER}

Portions of this document may be illegible in electronic image products. Images are produced from the best available original document. 


\begin{abstract}
The electrolytic oxidation in nitric acid of stainless steel, zirconium, Zircaloy-2, zirconium-uranium alloy, aluminum, and uranium-molybdenum alloy was demonstrated on a laboratory scale. The rate of chemical dissolution of $\mathrm{UO}_{2}$ in nitric acid was measured. Corrosion of stainless steel by these dissolver solutions was measured and found to be negligible. Electrolytic dissolution was demonstrated to be a practical technique for the first step in processing fuel elements of several types of power reactors.
\end{abstract}




\section{CONTENTS}

\section{$\underline{\text { Page }}$}

Iist of Tables and Figures

Introduction

Summary

Discussion $\quad 6$

Experimental Equipment and Procedures 6

Dissolution of Stalnless Steel in Nitric Acid 7

Dissolution of Zirconium and Z1rcaloy-2 in Nitric Actd II

Dissolution of Zr-U Alloy in Nitric Ac1d 13

Dissolution of Aluminum in Nitric Acid 17

Disintegration of Graphite-Uranium Fuel in Nitric Acid 18

Chemical Dissolution of $\mathrm{UO}_{2}$ in Nitric Acid 18

Gases Evolved During Electrolytic Dissolution in Nitric Acid 20

Electrolytic Properties of Tantalum and Columbium in High

Fields of Radiation 21

Bibliography 22 


\section{LIST OF TABLES AND FIGURES}

$\underline{\text { Page }}$

Table

I Effect of Temperature on Corrosion of Stainless Steel by Nitric Acid - Sta1nless Steel Solutions

II Corrosion Rates of Type 304L Coupons During Electrolytic Dissolution of Type 304L Anodes

III Electrolytic Dissolution of Zirconium in Nitric Acid

IV Electrolytic Dissolution of Detroit-Edison Core Elements

$\mathrm{V}$ Electrolyt1c Dissolution of $\mathrm{Zr}-10$ wt $\% \mathrm{U}$ Alloy in Nitric Acid

VI Electrolytic Dissolution of $\mathrm{Zr}-\mathrm{U}$ Alloy in $10 \mathrm{M} \mathrm{HNO}_{3}$

VII Electrolytic Dissolution of Heat-Treated $\mathrm{Zr}$ - Low U Alloys

VIII Cathode Gases Evolved During Electrolysis

Figure

1 Concentration of $\mathrm{Cr}^{+6}$ vs. Ampere-Hours

2 Current Ut1lization vs. Nitric Ac1d Concentration for Stainless Steel Dissolution

3 Electrolytic Dissolution of Stainless Steel

4 Mean Penetration Rate of $\mathrm{UO}_{2}$ Pellets in Nitric Acid 


\section{ELECTROLYTIC DISSOLUTION OF POWER REACTOR FUELS IN NITRIC ACID}

\section{INTRODUCTION}

Spent fuel elements from power reactors must be dissolved prior to uranium recovery by solvent extraction. Several processes, such as $\operatorname{Darex}^{(1)}$, which uses aqua regia; Zirflex(2), which uses ammonium fluoride - ammonium nitrate; and Sulfex(3), which uses sulfuric acid, have been proposed for the chemical dissolution of the cladding materials. The majorlty of these claddings, which prevent corrosion of fuel during irradiation, are stalnless steel or Zircaloy-2 ( $\mathrm{Zr}-1.5 \% \mathrm{Sn})$. The uranium fuel in most of the elements is in the form of $\mathrm{UO}_{2}$, although $\mathrm{Zr}-\mathrm{U}$ alloys, U-Al alloys, and compacts of $\mathrm{UO}_{2}$ and SS (cermets) comprise an appreclable fraction of the fuels that will require processing.

The Savannah RIver Laboratory and other sites have been developing techniques(4,5) for the electrolytic dissolution of these elements in nitric acid as the first processing step. This process is attractive in that the electrolyte, nitric acid, is compatible with existing radiochemical separations plants and with demonstrated processes for uranium recovery. Dissolver vessels made of expensive alloys would be necessary to resist chemical corrosion in the alternative processes. In principle, either stainless steel claddings or zirconium claddings can be electrolytically oxidized at the anode of a stainless steel cell. Electrolytic dissolution of elements clad with stainless steel was proposed as early as $1951^{(4)}$, but was never previously pursued to a development stage because of anticipated engineering difficulties.

Tantalum or columbium were selected as materials of construction for the inert (insoluble) anode basket in which the fuels are suspended during dissolution, because these metals have overvoltages of $180 \mathrm{v}$ and $40 \mathrm{v}$, respectively ${ }^{(6)}$. This property enables these metals to be used as electrical connectors below the liquid level without dissolving in the electrolyte, provided the applied voltage does not exceed the overvoltage. The high conductivity of nitric acid(7) should permit the operation of an electrolytic cell well below the overvoltage for these metals.

The laboratory work described in this report was undertaken to provide design data for a large-scale electrolytic dissolver.

\section{SUMMARY}

The dissolution of stalnless steel, zirconium or zircaloy-2, and aluminum by oxidation at the anode of an electrolytic cell containing nitric acid has been demonstrated on a laboratory scale. The technique of containing the fuels in a tantalum or columbium anode basket, which serves as the electrical connection between the source of power and the fuel, has also been tested, and the high overvoltage of these metals has been verified In a radiation field of $10^{7} \mathrm{rep} / \mathrm{hr}$ up to a total exposure of $10^{9} \mathrm{rep}$ $(\beta, \gamma)$. Electrical contact between the anodic fuel and the tantalum or columbium container was maintalned by periodicaliy tapping the anode basket with a hammer. In previous work this was done by vibration(4). 
Stainless steel anodes dissolve electrolytically in nitric acid at an average rate of 0.6 gram per ampere-hour. At a current density of $1 \mathrm{amp} / \mathrm{cm}^{2}$ this is equivalent to a penetration rate of $30 \mathrm{mlls}$ per hour. At acid concentrations below $2 \mathrm{M} \mathrm{HNO}_{3}$, side reactions reduce the number of grams dissolved per ampere-hour. No anomalous behavior was observed during the dissolution of irradiated stainless steel. Zirconium and Z1rcaloy-2 anodes disintegrate in nitric acld at an average rate of $1 \mathrm{~g} / \mathrm{amp}-\mathrm{hr}$. Approximately 15\% of the zirconium and $\mathrm{tin}$ dissolve; the remainder forms an insoluble $\mathrm{ZrO}_{2}$ precipitate. The $\mathrm{Zr}$ - low U alloys also disintegrate electrolytically in nitric acid; however, the $\mathrm{ZrO}_{2}$ that is formed contains from 10 to $50 \%$ of the total uranium. Aluminum dissolves electrolytically in nitric acid at a rate of $0.37 \mathrm{~g} / \mathrm{amp}-\mathrm{hr}$. The addition of $\mathrm{Hg}^{+2}$ does not enhance this rate. Fuels consisting of graphite impregnated with $\mathrm{UC}_{2}$ and $\mathrm{UO}_{2}$ can be disintegrated electrolytically in boiling $10 \mathrm{M} \mathrm{HNO}_{3}$; the sludge contains $0.1 \%$ of the total uranium.

A stainless steel dissolver was corroded by nitric acid solutions containing dissolved stainless steel $\left(\mathrm{Fe}^{+3}, \mathrm{Cr}^{+3}, \mathrm{Ni}^{+2}\right)$ at a rate of several mils per year at $90^{\circ} \mathrm{C}$. At this temperature $\mathrm{UO}_{2}$ dissolves in solutions contalning $5 \mathrm{M} \mathrm{HNO}_{3}$ at a rate in excess of $150 \mathrm{mils} / \mathrm{hr}$.

\section{DISCUSSION}

\section{EXPERIMENTAL EQUIPMENT AND PROCEDURES}

The results reported herein were obtalned primarlly with glass equipment in which the maximum current during dissolution was 100 amperes at a maximum potential of 25 volts. Some results from a 500-ampere electrolytic dissolver are also included. In most cases baskets made of tantalum or columbium served as containers which conducted current to the various metals and alloys that were to be dissolved. In some cases, such as the dissolution of the $\mathrm{Zr}$ - low U alloys, direct electrical contact between the power supply and metal was used in order to eliminate the variable of contact resistance between the metal and the container. Tantalum or columbium cathodes were used in most of the tests. The glass vessels employed for the tests were equipped with reflux condensers in those cases where the acld was to be returned to the dissolver. No effort was made to scrub the oxides of nitrogen in the condenser, and undoubtedly some acid was lost. Consequently, acid consumption per mole of metal dissolved varied and was higher than that expected on the basis of stolchiometry.

Current utilizations were obtalned by measuring the current over a period of time and determining the loss in welght of the anode for that period. In those experiments in which it was desired to measure the gases produced at the cathode and anode a standard H-cell was employed to prevent mixing of the gas from each electrode. The gases were expanded into an evacuated bulb and analyzed by mass spectrometry. Specific descriptions of various techniques and equipment have been previously published(8-15), but some additional details are given in the discussion of results. 


\section{DISSOLUTION OF STAINLESS STEEL IN NITRIC ACID}

Stainless steel anodes were dissolved electrolytically in nitric acid at a rate of $0.58 \mathrm{~g} / \mathrm{amp}-\mathrm{hr}$. One ampere-hour will theoretically oxidize $0.59 \mathrm{~g}$ of Type 304 stainless steel ( $19 \% \mathrm{Cr}, 9.5 \% \mathrm{N1}$ ) to $\mathrm{Fe}^{+3}, \mathrm{Cr}^{+6}$, and $\mathrm{Ni}^{+2}$. Wide variations of temperature ( 15 to $113^{\circ} \mathrm{C}$ ) or current density $\left(0.025\right.$ to $\left.3.0 \mathrm{amp} / \mathrm{cm}^{2}\right)$ had no effect on the current utilization. Analyses of the electrolyte during dissolution showed that the iron, chromium, and nickel in the steel were being oxidized to $\mathrm{Fe}^{+3}, \mathrm{Cr}^{+6}$, and $\mathrm{Ni}^{+2}$. As the dissolution proceeded the $\mathrm{Cr}^{+6}$ was reduced to $\mathrm{Cr}^{+3}$ by the oxides of nitrogen that were liberated at the cathode. The time required 1 s dependent upon the rate of dissolution and the solubility of $\mathrm{NO}$ and $\mathrm{NO}_{2}$. Figure $I$ is a typlcal plot of concentration of $\mathrm{Cr}^{+6} \mathrm{vs}$. amp-hr in one liter of $4.3 \mathrm{M} \mathrm{HNO}_{3}$. The rate of reduction of $\mathrm{Cr}^{+6}$ to $\mathrm{Cr}^{+3}$ is apparently independent of $\mathrm{Cr}^{+6}$ concentration.

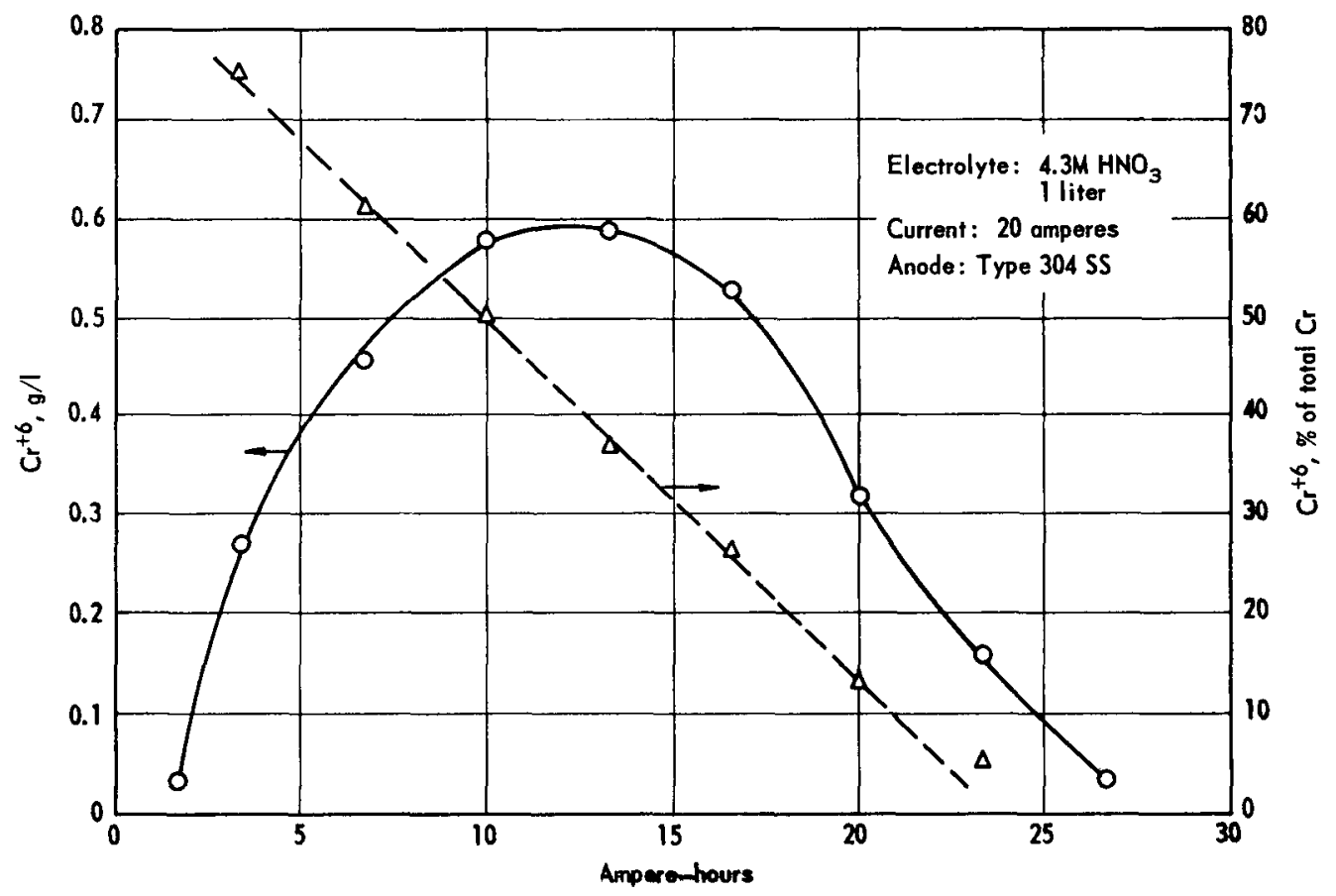

FIG. 1 CONCENTRATION OF $C R^{+6}$ VS. AMPERE - HOURS

In 0.5 to $2 \mathrm{M} \mathrm{HNO}_{3}$, side reactions decrease the current utilization (Figure 2). Measurement and analysis of anode gas from a $1 \mathrm{M} \mathrm{HNO}_{3}$ electrolyte, in which stainless steel dissolves at a rate of $0.4 \mathrm{~g} / \mathrm{amp}-\mathrm{hr}$, showed that the formation of oxygen accounted for one-third of the decrease in current utilization. Another side reaction is presumed to be the oxidation of nitrite ion. In greater than $2 \mathrm{M} \mathrm{HNO}_{3}$ the current utilization was $0.58 \pm 0.02(1 \sigma) \mathrm{g} / \mathrm{amp}-\mathrm{hr}$. The presence of dissolved stainless steel $(30 \mathrm{~g} / 1)$ increased the current utilization slightly to $0.625 \pm .03(1 \sigma) \mathrm{g} / \mathrm{amp}-\mathrm{hr}$. The presence of $0.5 \mathrm{M} \mathrm{U}$ in the electrolyte did 
not change the current utilization. The integrated average dissolution rate of a stainless steel anode in $2 \mathrm{M} \mathrm{HNO}_{3}$ over the concentration range 0 to $30 \mathrm{~g} / 1$ of dissolved stainless steel was $0.60 \mathrm{~g} / \mathrm{amp}-\mathrm{hr}$. On an average, 0.06 mole of ac1d was consumed per gram of stainless steel dissolved.

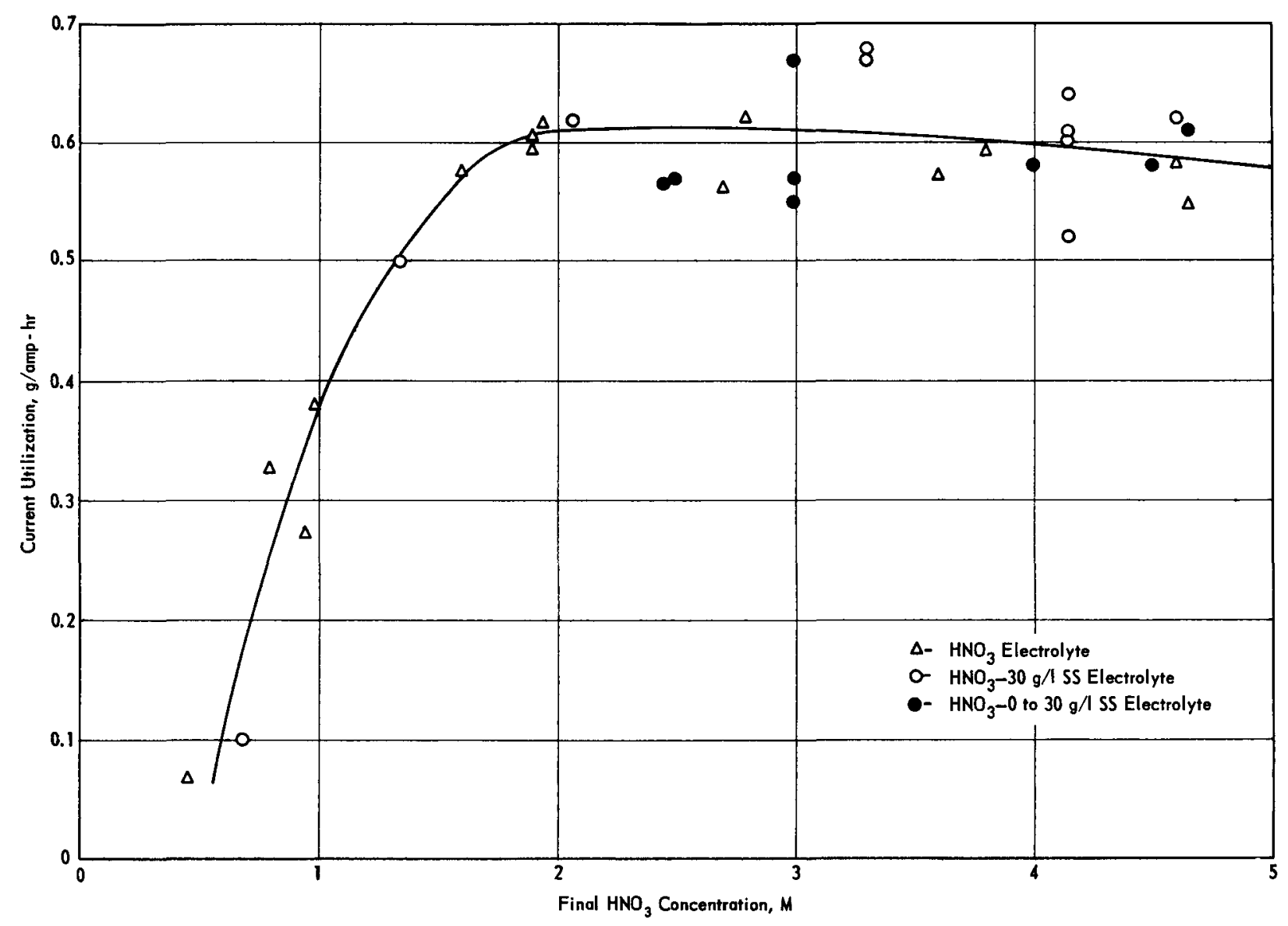

FIG. 2 CURRENT UTILIZATION VS. NITRIC ACID CONCENTRATION FOR STAINLESS STEEL DISSOLUTION

Approximately 2 wt $\%$ of the stalnless steel anode does not dissolve in the electrolyte. Other workers (4) have indicated that the residue that remains after the electrolytic dissolution of Type 347 stainless steel is $\mathrm{CbC}$. The residue obtained during the dissolution of Type 304 stainless in nitric acid has been identified as undissolved stainless steel by $X$-ray diffraction and emission spectra. Type 304 stainless is not stabilized with columbium. Occasionally a sludge of iron oxide develops on the surface of the stainless steel anode at the point where It makes contact with the tantalum or columblum anode basket. Arcing between the tantalum anode contalner and the stainless steel anodes promotes the formation of this oxide, especially if the stainless steel overheats. This arcing, which results from an increase in resistance 
at the point of contact, has a tendency to p1t the tantalum basket and, if very severe, to burn a hole in 1t. Shaking or vibrating the anode basket at a frequency of the order of ten times per hour creates new points of contact and minimizes the arcing. In the laboratory-scale electrolytic dissolver, in which currents were a maximum of 100 amperes, arcing was not severe and contact between basket and charge was easily maintained. Figure 3 is a plot of voltage vs. time for an electrolytic dissolution in which $99.7 \%$ of the stainless steel was dissolved, less 1.5\% accumulated as a sludge in the bottom of the vessel.

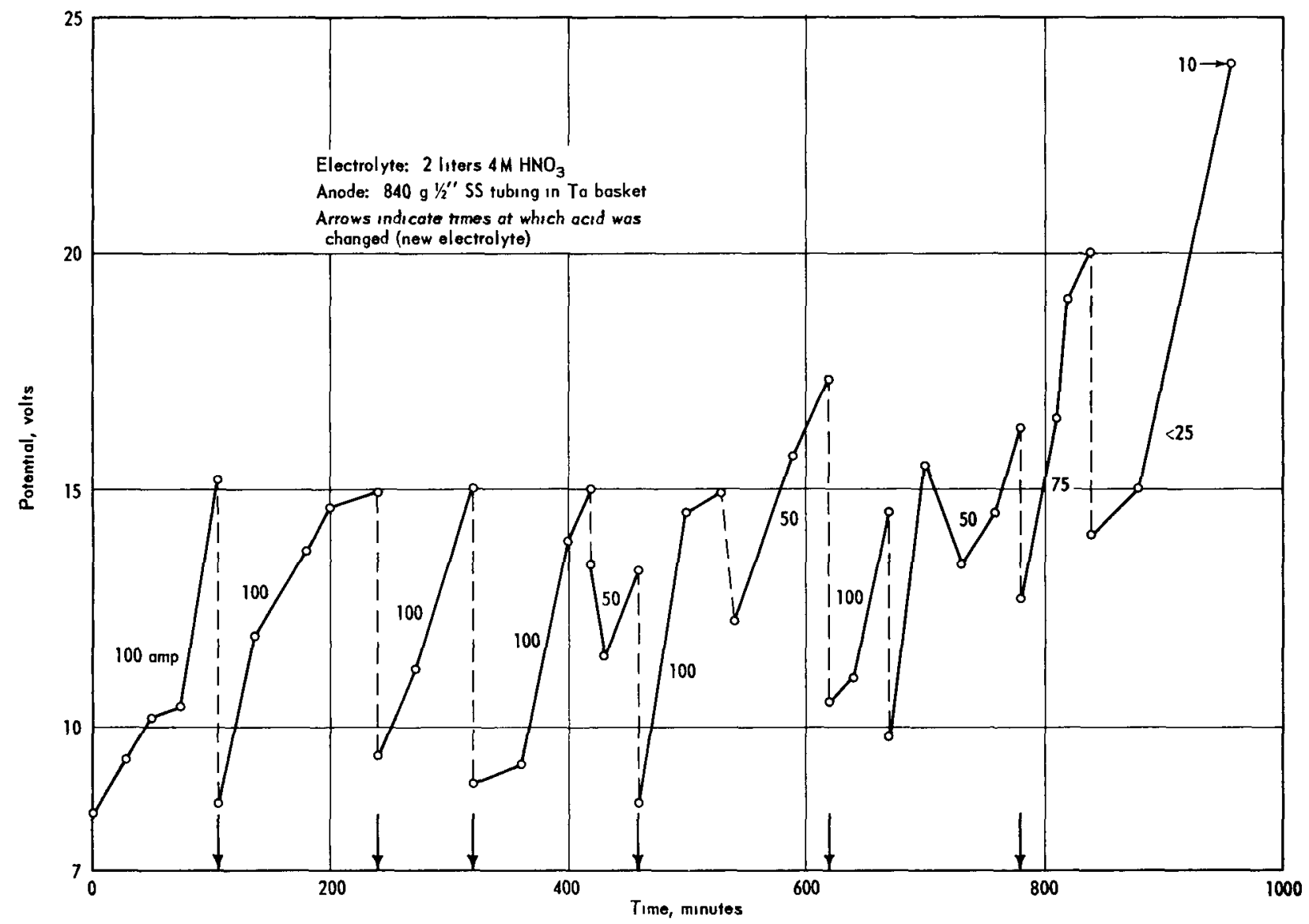

FIG. 3 ELECTROLYTIC DISSOLUTION OF STAINLESS STEEL Volts vs. Time

Nitric acid solutions of electrolytically dissolved stainless steel are corrosive to stainless steel alloys ${ }^{14)}$. This chemical attack by the electrolyte must be controlled. McIntosh and Evans $(26)$ concluded that the corrosion of the steel alloy ( 18 wt $\% \mathrm{Cr}, 13 \mathrm{wt} \% \mathrm{N1}$, $\mathrm{Cb}$ stabilized) studied by them was caused by an oxidation-reduction cycle involving chromium and nitric acid. The $\mathrm{Cr}^{+6}$ ions were able to oxidize, and so remove, some of the hydrated $\mathrm{Cr}^{+3}$ oxide in the protective 
layer of the alloy. In electrolytic dissolving, the $\mathrm{Cr}^{+6}$ produced at the anode is subsequently reduced by the oxides of nitrogen produced at the cathode. At 85 to $90^{\circ} \mathrm{C}$, the corrosion rate $(17)$ of Type $304 \mathrm{~L}$ stainless steel is a few mils per year. Tables I and II summarize these data. The blue solutions are $\mathrm{Cr}^{+3}$ and the yellow are $\mathrm{Cr}^{+6}$.

\section{TABLE I}

Effect of Temperature on Corrosion of Stalnless Steel by Nitric Ac1d - Stalnless Steel Solutions Solution contalned $20 \mathrm{~g} / 1$ of Type $304 \mathrm{~L}$ stalnless steel electrolytically dissolved in $10 \mathrm{M} \mathrm{HNO}_{3}$. Corrosion rates expressed in $\mathrm{mlls} / \mathrm{yr}$.

$113^{\circ} \mathrm{C}$

Stainless Steel Specimen $50^{\circ} \mathrm{C}$ 60 $0^{\circ} \mathrm{C} 85^{\circ} \mathrm{C}$ (boiling)

$\begin{array}{lllll}304 \mathrm{~L} & 3.5 & 6.7 & 11.8 & 89 \\ 304 \mathrm{~L} & 3.5 & 6.8 & 15.4 & 91\end{array}$

$304 \mathrm{~L}$ welded

$\begin{array}{llll}3.1 & 7.6 & 13.1 & 99\end{array}$

$304 \mathrm{~L}$ welded

$\begin{array}{llll}3.8 & 9.6 & 13.4 & 103\end{array}$

$309 \mathrm{cb}$

$\begin{array}{llll}3.9 & 9.6 & 14.7 & 124\end{array}$

$309 \mathrm{Cb}$

$\begin{array}{llll}3.9 & 8.7 & 15.1 & 119\end{array}$

$309 \mathrm{Cb}$ welded

$\begin{array}{llll}4.2 & 8.7 & 15.1 & 123\end{array}$

$309 \mathrm{Cb}$ welded

$\begin{array}{llll}4.0 & 8.4 & 15.7 & 127\end{array}$

\section{TABLE II}

Corrosion Rates of Type 304L Coupons During Electrolytic D1ssolution of Type 304L Anodes

Initial $\mathrm{HNO}_{3}$ Conc: $6 \mathrm{M}$

Temperature: 85 to $90^{\circ} \mathrm{C}$

Initial Stainless Steel Conc: $0 \mathrm{~g} / \mathrm{l}$

\begin{tabular}{|c|c|c|c|}
\hline \multirow[b]{2}{*}{$\begin{array}{c}\text { Test } \\
\text { Duration, } \\
\text { hr }\end{array}$} & \multicolumn{3}{|c|}{ Final Solution } \\
\hline & $\begin{array}{c}\text { Stalnless } \\
\text { Steel Conc, } \\
g / 1 \\
\end{array}$ & Color & $\begin{array}{c}\text { Estimated } \\
\text { HNO }_{3} \text { Conc, } \mathrm{M}\end{array}$ \\
\hline 23 & 43 & Blue & 3.0 \\
\hline 24 & 30 & Blue & 4.0 \\
\hline 19 & 34 & Blue & 3.7 \\
\hline 23 & 21 & Blue & 4.5 \\
\hline 23 & 33 & Blue & 3.7 \\
\hline 21 & 23 & Blue & 4.4 \\
\hline 22 & 37 & Yellow-green & 3.4 \\
\hline 21 & 39 & Yellow & 3.3 \\
\hline
\end{tabular}

Penetration Rate, mils/yr

Coupon Coupon Coupon

No. 1 No. 2 №. 3

$1.2 \quad 1.0 \quad-$

1.50 .1 -

$1.7 \quad 1.4 \quad-$

$1.4 \quad 1.6 \quad 1.2$

$3.4 \quad 3.5 \quad 1.3$

$2.1 \quad 2.5 \quad 1.8$

$8.1 \quad 8.8 \quad 8.3$

$13.2 \quad 13.2 \quad-$ 
Irradiated stainless steel dissolves electrolytically in nitric acid with no apparent unusual behavior(15). Four fuel rods of the N.S. Savannah type ( $\mathrm{UO}_{2}$ pellets clad in stainless steel), which were irradiated to $1900 \mathrm{MWD} / \mathrm{T}$, were dissolved in pairs in $7.0 \mathrm{M} \mathrm{HNO}_{3}$. The dissolutions were stopped after all the $\mathrm{UO}_{2}$ and $60 \%$ of the stainless steel (including end fittings) had dissolved. The final solution was filtered and diluted about $20 \%$ for solvent extraction feed. The composition of this feed solution was $0.6 \mathrm{M}$ UNH, $2.75 \mathrm{M} \mathrm{HNO}_{3}, 30 \mathrm{~g} \mathrm{SS} /$ liter, $4.2 \times 10^{6} \mathrm{Pu} \alpha$ disintegrations $/(\mathrm{min})(\mathrm{ml})$, and $1.7 \times 10^{7} \gamma$ counts $/(\mathrm{min})(\mathrm{ml})$. Pertinent decontamination factors and the solvent extraction flowsheet have been previously reported(15). No difficulties were encountered either in the electrolytic dissolution of the irradiated stainless steel cladding or in the chemical dissolution of the 1rradiated $\mathrm{UO}_{2}$ core. No problems of electrical contact between the elements and the columbium anode basket developed during the two experiments.

A depleted uranium mockup of an element for the Army Package Power Reactor was dissolved electrolytically in $10 \mathrm{M} \mathrm{HNO}_{3}$. This element is a 20-mil plate of stainless steel - $\mathrm{UO}_{2}$ cermet clad with $5 \mathrm{mils}$ of stainless steel. The core of the element is 26 wt $\% \mathrm{UO}_{2}$. The element was dissolved in a tantalum basket at a current utilization of $0.57 \mathrm{~g}$ of SS/amp-hr. Approximately 5.5\% of the stainless steel collected as a very finely divided sludge in the bottom of the dissolver vessel. In addition, $1.4 \%$ of the element falled to dissolve because of poor electrical contact with the anode basket. These fragments contained $0.2 \%$ of the total uranium. Approximately $0.4 \%$ of the uranium was found in the finely divided sludge on the bottom of the vessel; half of the uranium In the sludge was recovered by bolling the sludge in $10 \mathrm{M} \mathrm{HNO}_{3}$ for 3 hours. The balance of the uranium, $99.4 \%$, was found in the dissolver solution.

\section{DISSOLUTION OF ZIRCONIUM AND ZIRCALOY-2 IN NITRIC ACID}

Zirconium and Zircaloy-2 disintegrate when they are used as the anode of a cell in which the electrolyte is nitric acid. At least two of the competing anode reactions are:

$$
\begin{aligned}
& \text { (1) } \mathrm{Zr}+2 \mathrm{H}_{2} \mathrm{O} \rightarrow \mathrm{ZrO}_{2}+4 \mathrm{H}^{+}+4 \mathrm{e}^{-} \\
& \text {(2) } \mathrm{Zr}+\mathrm{H}_{2} \mathrm{O} \longrightarrow \mathrm{ZrO}^{++}+2 \mathrm{H}^{+}+4 \mathrm{e}^{-}
\end{aligned}
$$

The zirconium is oxidized anodically in nitric acid by diffusion of the oxygen ions into the metal lattice ${ }^{(18)}$. The resulting oxide layer is less dense than its base metal, so that $1 t$ spalls off in the nitric acid and settles rapidly to the bottom of the anode basket. About 15\% of the zirconium or Zircaloy-2 dissolves, and the balance precipitates as $\mathrm{ZrO}_{2}$ by reaction (1) above. The average disintegration rate is $1 \mathrm{~g}$ zirconium or Zircaloy-2 per amp-hr in 1 to $10 \mathrm{M} \mathrm{HNO}_{3}$. Six tests were made on reactor-grade zlrconium to determine the effect of acid strength and current density on the split between the soluble Zrot+ and the insoluble $\mathrm{ZrO}_{2}$. The results are shown in Table III. The quantity of zirconium 
put into solution was not affected by changing either the concentration of the ac1d from 4 to $16 \mathrm{M}$, the current density from 0.13 to $0.41 \mathrm{amp} / \mathrm{cm}^{2}$, or the temperature from 30 to $100^{\circ} \mathrm{C}$. The mass of zirconium dissolved per amp-hr of charge ranged from 0.8 to $1.3 \mathrm{~g}$. No explanation for this wide range in effectiveness is apparent. The behavior of Zircaloy-2 is analogous, with $15 \%$ of the tin dissolving and the remainder precipitating. Usually the initiation of the dissolution of zirconium in nitric acid is not instantaneous. The electrolyte is maintained near the boiling point, at which temperature the $\mathrm{UO}_{2}$ cores dissolve rapidly. At temperatures of $85^{\circ} \mathrm{C}$ or greater the zirconium disintegration can be initiated easily in $5 \mathrm{M} \mathrm{HNO}_{3}$ and continued, once initiated, in $>1 \mathrm{M} \mathrm{HNO}_{3}$. This inftiation phenomenon is associated with the rate of formation of the $\mathrm{ZrO}_{2}$ layer on the metal surface and depends upon the history of the metal. Easier initiation at high nitric acid concentration and high temperature is consistent with more rapid oxide formation under these conditions. No quantitative investigation of the rate of oxide formation and its effect on the induction period was attempted.

TABLE III

Electrolytic Dissolution of Zirconium in Nitric Ac1d

\begin{tabular}{|c|c|c|c|}
\hline $\begin{array}{l}\mathrm{HNO}_{3}, \\
\mathrm{M}\end{array}$ & $\begin{array}{c}\text { Anode } \\
\text { Current Density, } \\
\mathrm{amp} / \mathrm{cm}^{2}\end{array}$ & $\begin{array}{l}\text { Current Ut1lization, } \\
\mathrm{g} / \mathrm{amp}-\mathrm{hr}\end{array}$ & $\begin{array}{c}\mathrm{Zr} \text { D1ssolved, } \\
\not 6\end{array}$ \\
\hline 4 & 0.19 & 0.8 & 14 \\
\hline 10 & 0.13 & 0.8 & 16 \\
\hline 10 & 0.13 & 1.0 & 15 \\
\hline 10 & 0.26 & 1.3 & 15 \\
\hline 10 & 0.41 & 1.1 & 14 \\
\hline 16 & 0.24 & 1.1 & 14 \\
\hline
\end{tabular}

The $\mathrm{ZrO}_{2}$ sludge that was produced by the electrolytic dissolution of Zircaloy-2-clad $\mathrm{UO}_{2}$ fuels in boling $10 \mathrm{M} \mathrm{HNO}_{3}$ contalned $0.15 \%$ of the total uranium. Half of this was recovered by bolling the sludge in IOM $\mathrm{HNO}_{3}$ for 3 hours. X-ray diffraction analysis of this sludge indicated a highly amorphous solid with weak $\mathrm{ZrO}_{2}$ lines. No other solid phase could be detected. In the 500-amp dissolver the acid consumption averaged 3 moles per mole of zirconium disintegrated.

Unirradiated Detroit-Edison core elements (U - 10\% Mo clad with 4 mils of zirconium) were dissolved electrolytically in $10 \mathrm{M} \mathrm{HNO}_{3}$. Two experiments were performed in which the fuel pins were connected directly to the power source. Direct current was used in one experiment and alternating current in the other. Since a tantalum cathode was used in each run, the imposed $A C$ potential produced a half-wave rectified current through the cell. It was necessary to heat the solutions above $50^{\circ} \mathrm{C}$ before starting the electrolysis. During dissolution the voltage required to maintain 10 amperes dropped about fivefold, presumably when 
the cladding disappeared, and remalned fairly constant until dissolution of the core was complete. In contrast to $\mathrm{UO}_{2}$, uranium metal and $\mathrm{U}-\mathrm{Mo}$ alloy dissolve electrolytically in nitric acid. The sluage was leached

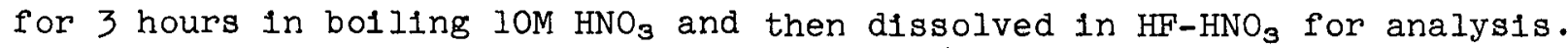
The loss of uranium to the residue was $0.005 \%$. Pertinent data are given in Table IV.

TABLE IV

Electrolytic Dissolution of Detroit-Edison Core Elements

\begin{tabular}{|c|c|c|}
\hline Run Number & PRDC - I & PRDC - 2 \\
\hline Power Source & DC & $\mathrm{AC}$ \\
\hline $\begin{array}{l}\text { Avg Current Utilization(a), } \\
\text { g/amp-hr }\end{array}$ & 2.1 & 3.3 \\
\hline $\begin{array}{l}\text { Distribution of Original } \\
\text { Uranium, } \% \\
\text { Dissolver Solution } \\
\text { Leach Solution } \\
\text { Preclpitate }\end{array}$ & $\begin{array}{l}\sim 100 \\
0.005 \\
<0.005\end{array}$ & $\begin{array}{l}\sim 100 \\
0.008 \\
<0.004\end{array}$ \\
\hline $\begin{array}{l}\text { Distribution of Original } \\
\text { Molybdenum, } \% \\
\text { Dissolver Solution } \\
\text { Leach Solution } \\
\text { Preclpitate }\end{array}$ & $\begin{array}{r}99 \\
0.8 \\
0.2\end{array}$ & $\begin{array}{r}99 \\
0.8 \\
0.2\end{array}$ \\
\hline $\begin{array}{l}\text { Distribution of Original } \\
\text { Z1rconium, } \% \\
\text { Dissolver Solution } \\
\text { Leach Solution } \\
\text { Precipitate }\end{array}$ & $\begin{array}{r}13 \\
6 \\
81\end{array}$ & $\begin{array}{r}13 \\
2 \\
85\end{array}$ \\
\hline
\end{tabular}

(a) The average of the electrolytic attack on the cladding and the combined electrolytic and chemical attack on the core.

Solutions of Zircaloy-2 that were electrolytically dissolved in $10 \mathrm{M}$ $\mathrm{HNO}_{3}$ did not accelerate the corrosion of stainless steel. Corrosion rates of welded and wrought Type $304 \mathrm{~L}$ and Type $309 \mathrm{Cb}$ in such solutions containing $8.5 \mathrm{~g} / \mathrm{l}$ of dissolved zirconium were less than $3 \mathrm{mils} / \mathrm{yr}$. All the corrosion tests were made at the bolling point $\left(113^{\circ} \mathrm{C}\right)$. There is no indication that solutions containing nitric acid and dissolved Zircaloy would be corrosive to an electrolytic dissolver made of stalnless steel.

\section{DISSOLUTION OF Zr-U ALLOY IN NITRIC ACID}

The $\mathrm{Zr}$ - low U alloys are the only major type of power reactor fuel element that cannot be dissolved electrolytically in nitric acid without a high loss of uranium to the sludge. During electrolysis the surface of the element is oxidized to $\mathrm{ZrO}_{2}$, whlch spalis off and carries with it a variable but high percentage of the uranium. Table $V$ summarizes the data for the disintegration of $\mathrm{Zr}-10 \mathrm{wt} \% \mathrm{U}$ alloy. The percentage of zirconium dissolved is twice that dissolved from pure zirconium, but uranium losses varied from 10 to 50\%, even after bolling the sludge in 
nitric acid. Loss of uranium decreased with increasing acidity, but no correlation with temperature was observed. An attempt was made to effect better dissolution of the uranium by interrupting the electric current to promote descaling of the surface of the alloy and produce a smoother dissolution. The particles of $\mathrm{ZrO}_{2}$ produced during current interruption are finer than those normally observed; therefore, it was considered possible that the occluded uranium might be more readily leached from these particles. Two schemes for interrupting the current were tried. One was simply to impose an AC potential across the cell. Since the tantalum cathode wlll not conduct current anodically the cell served as a half-wave rectifier and a 60-cycle interruption was achieved. The second technique interposed a revolving, brush-contacted commutator between the standard DC power supply and the cell. The output was a square wave with a $90 \%$ use cycle and a variable (0 to 27 cps) interruption frequency. The results given in Tabie VI do not demonstrate any clearly defined advantage for operation with current interruption. The lowest losses of uranium to the precipitate ( 13 and 14\%) were observed during operation with AC voltage; however, losses were not consistently low.

TABLE V

Electrolytic Dissolution of $\mathrm{Zr}-10 \mathrm{wt} \% \mathrm{U}$ Alloy in Nitric Acid

\begin{tabular}{|c|c|c|c|c|c|c|}
\hline $\begin{array}{c}\text { Temperature } \\
\text { During } \\
\text { Electrolysis, } \\
{ }^{\circ} \mathrm{C} \\
\end{array}$ & $\begin{array}{c}\mathrm{HNO}_{3} \text { Conc, } \\
\mathrm{M} \\
\end{array}$ & $\begin{array}{c}\mathrm{Al}\left(\mathrm{NO}_{3}\right)_{3} \text { Conc, } \\
\mathrm{M} \\
\end{array}$ & $\begin{array}{l}\text { Duration of } \\
\text { Leach } \\
\text { with } \\
\text { Boiling } \\
\text { lOM } \mathrm{HNO}_{3} \text {, } \\
\mathrm{hr} \\
\end{array}$ & $\begin{array}{c}\mathrm{Zr} \\
\text { Dissolved } \\
\text { During } \\
\text { Electrolysis, } \\
0 \\
\end{array}$ & $\begin{array}{l}\text { U Loss to Zro } \\
\text { After } \\
\text { Electrolysis }\end{array}$ & $\begin{array}{l}\frac{\text { Ppt, } q}{\text { After }} \\
\text { Leaching }\end{array}$ \\
\hline $20-90$ & 4 & 0 & 1.5 & 30 & (a) & 52 \\
\hline $20-100$ & 10 & 0 & 2 & 33 & 46 & 34 \\
\hline $70-107$ & 16 & 0 & 2 & 25 & 37 & 12 \\
\hline 120 & 16 & 0 & 9 & 40 & (a) & 31 \\
\hline 110 & 10 & 0.5 & None & 22 & 73 & -- \\
\hline $85-114$ & 13 & 0.4 & None & 24 & 69 & -- \\
\hline $14-46$ & 16 & 0 & 1.5 & 35 & (a) & 19 \\
\hline $15-30$ & 16 & 0 & 2 & 22 & 36 & 25 \\
\hline $14-20$ & 16 & 0 & 2 & 26 & 41 & 24 \\
\hline $18-46$ & 16 & Sat'd & None & 23 & 31 & -- \\
\hline $16-20$ & 16 & Sat'd & 2 & 38 & 13 & 11 \\
\hline
\end{tabular}

(a) Residue digested in original dissolver solution immediately after electrolytic dissolution. 
TABIE VI

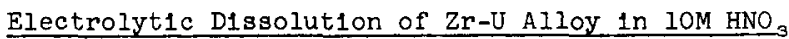

\begin{tabular}{|c|c|c|c|c|c|c|c|c|}
\hline Anode & $\begin{array}{l}\text { Impressed } \\
\text { Voltage }\end{array}$ & $\begin{array}{c}\text { Temp } \\
\text { During } \\
\text { Electroly- } \\
\text { sis, }{ }^{\circ} \mathrm{C} \\
\end{array}$ & $\begin{array}{l}\text { Current } \\
\text { Dens1ty, } \\
\text { amp/cm }{ }^{2}\end{array}$ & $\begin{array}{c}\text { Current } \\
\text { Utilization, } \\
\mathrm{g} / \mathrm{amp}-\mathrm{hr} \\
\end{array}$ & $\begin{array}{c}\text { Duration } \\
\text { of Leach } \\
\text { W1th } \\
\text { Bo1ling } \\
\text { 1OM HNO } \\
\text { hr } \\
\end{array}$ & $\begin{array}{c}\mathrm{Zr} \\
\text { Dissolved } \\
\text { During } \\
\text { Electroly- } \\
\text { sis. } 8 \\
\end{array}$ & $\begin{array}{l}\mathrm{U} \text { Loss to } \\
\text { After } \\
\text { Electroly- } \\
\text { s1s }\end{array}$ & $\begin{array}{c}\mathrm{ZrO} \mathrm{O}_{2} \text { Ppt, } \% \\
\text { After } \\
\text { Leaching }\end{array}$ \\
\hline $\mathrm{Zr}-5.5 \% \mathrm{U}$ & $\mathrm{DC}$ & $46-87$ & - & 1.0 & 3 & 15 & 29 & 22 \\
\hline $\mathrm{Zr}-5.5 \% \mathrm{U}$ & $D C$ & $55-80$ & 0.45 & 0.86 & 3 & 16 & 47 & 30 \\
\hline $\mathrm{Zr}-5.5 \% \mathrm{U}$ & $\mathrm{AC}$ & $50-97$ & 0.40 & 0.92 & 3 & 14 & 52 & 14 \\
\hline $\mathrm{Zr}-5.5 \% \mathrm{U}$ & $\begin{array}{l}\text { Interrupted } \\
\text { DC (20 cps) }\end{array}$ & $57-69$ & 0.40 & 0.45 & 3 & 17 & 42 & 28 \\
\hline $\mathrm{zr}-9.4 \% \mathrm{U}$ & $\mathrm{AC}$ & $27-41$ & 0.06 & 0.54 & 3 & 37 & 15 & 13 \\
\hline $2 \mathrm{r}-9.4 \% \mathrm{U}$ & $A C$ & - & 0.22 & 0.96 & - & 22 & 60 & - \\
\hline $\mathrm{Zx}-9.4 \% \mathrm{U}$ & $A C$ & $31-61$ & 0.26 & 1.1 & 3 & 17 & 33 & 24 \\
\hline $\mathrm{Zr}-9.4 \% \mathrm{U}$ & $\begin{array}{l}\text { Intermupted } \\
\text { DC (10 cps) }\end{array}$ & $56-80$ & 0.47 & 0.67 & 3 & 17 & 52 & 29 \\
\hline $\mathrm{Zr}-9.4 \% \mathrm{U}$ & $\begin{array}{l}\text { Interrupted } \\
\text { DC (20 cps) }\end{array}$ & $48-83$ & 0.51 & 0.51 & $\begin{array}{l}\text { 1) } 8 \\
\text { 2) } 8(a)\end{array}$ & 29 & $\begin{array}{l}38 \\
33\end{array}$ & $\begin{array}{l}33 \\
19\end{array}$ \\
\hline $\mathrm{Zr}-9.4 \not \mathrm{U}$ & $\begin{array}{l}\text { Interrupted } \\
\text { DC (27 cps) }\end{array}$ & $5 I-77$ & 0.52 & 0.71 & 3 & 16 & 56 & 32 \\
\hline $\mathrm{Zr}-16.7 \% \mathrm{U}$ & $\begin{array}{l}\text { Interrupted } \\
\text { DC (20 cps) }\end{array}$ & $42-74$ & 0.47 & 0.50 & 3 & 52 & 36 & 21 \\
\hline
\end{tabular}

(a) Sludge was ground with mortar and pestle between first and second leaches.

The fact that variations in the current density, ac1d strength, temperature, and type of voltage had no consistent effect on the high uranium loss to the sludge would support the conclusion that the uranium was being occluded in the $\mathrm{ZrO}_{2}$ precipitate. In an attempt to influence this occlusion, chemicals such as sodium dichromate, hydrogen peroxide, and hydrofluoric acid $(0.03 \mathrm{M})$ were added individually to the nitric acid electrolyte. No benefit from these additions was observed. Only small quantities of uranium were recovered from the sludge when it was bolled in sodium hydroxide, fused in sodlum hydroxide, or roasted and then boiled in nitric acid. When the electrolysis was performed in sodium nitrate solutions to study the effect of $\mathrm{pH}$ on uranium loss, a hydrated oxide of uranium precipitated in neutral or basic solutions. The addition of sodium carbonate or bicarbonate to the electrolyte decreased the precipitation of the hydrated uranium oxide by the formation of a soluble uranium carbonate complex. In all cases in which the electrolyte contained sodium nitrate, the uranium losses were high (28 to 62\%). When potassium lodide was used as the electrolyte, uranium loss to the sludge ranged from 9 to 15\%. The solution in the vicinity of the anode was deeply colored by $\mathrm{I}_{3}{ }^{-}$ion from the oxidation of iodine at the surface. Iodine reacts with zirconium to form an insoluble zirconium-1odine compound. Other electrolytes tried were sodium carbonate, sodium bicarbonate, sodium hydroxide, phosphoric ac1d, acidic 
monosodium phosphate, and oxalic acid. In all of these cases the cell did not conduct sufficient current with the $\mathrm{Zr}$ - low U alloy as anode for the disintegration to be measured.

The structures of both the alloy and the $\mathrm{ZrO}_{2}$ sludge were studied in an attempt to determine the mechanism by which the uranium was held in the sludge. $\mathrm{Zr}$ - low U alloy usually consists of two uranium-containing phases: one is the dispersed $\delta$ phase, $U Z r_{3}-U Z r_{4}$, and the other is the $\epsilon$ phase, a matrix of zirconium containing dissolved uranium. To test the hypothesis that the uranium in the sludge was originally that in the $\delta$ phase, the $\delta$ phase was eliminated by heat treatment. Pieces of $\mathrm{Zr}$ - low U alloy were heated to $850^{\circ} \mathrm{C}$, where $\delta$ phase dissolves in the $\mathrm{Zr}-\mathrm{U}$ matrix, and then were water quenched to retain the uranium in a supersaturated solution. This solution-quenched alloy was immediately dissolved electrolytically. The exceptionally high uranium content of the sludge (Table VII) eliminated the possibility that the $\delta$ phase was solely responsible for the loss of uranlum to the $\mathrm{ZrO}_{2}$.

TABIE VII

Electrolytic Dissolution of Heat-Treated $\mathrm{Zr}$ - Low U Alloys

\begin{tabular}{|c|c|c|c|c|c|c|c|}
\hline \multirow{2}{*}{$\begin{array}{c}\text { Heat } \\
\text { Treatment } \\
\end{array}$} & \multirow[b]{2}{*}{ A.11oy } & \multicolumn{3}{|c|}{$\begin{array}{c}\text { Distribution of Original } \\
\text { Uranium, } \%\end{array}$} & \multicolumn{3}{|c|}{$\begin{array}{l}\text { Distribution of Original } \\
\text { Zirconium, } \%\end{array}$} \\
\hline & & Electrolyte & Ieach & Sludge & Electrolyte & Leach & Sludge \\
\hline $\begin{array}{l}\text { Slow cool } \\
\text { (double phase) }\end{array}$ & $\mathrm{Zr}-10$ wt $\$ \% \mathrm{U}$ & 48.5 & 11.1 & 40.5 & 28.9 & 3.1 & 68.0 \\
\hline $\begin{array}{l}\text { Slow cool } \\
\text { (double phase) }\end{array}$ & $\mathrm{zr}-16 \mathrm{wt} \% \mathrm{U}$ & 55.3 & 9.0 & 35.7 & 29.9 & 5.6 & 64.7 \\
\hline $\begin{array}{l}\text { Solution } \\
\text { quench } \\
\text { (single phase) }\end{array}$ & $\mathrm{Zr}-10$ wt $\not 6 \mathrm{U}$ & 32.3 & 3.4 & 64.7 & 32.2 & 2.8 & 64.3 \\
\hline $\begin{array}{l}\text { Solution } \\
\text { quench } \\
\text { (single phase) }\end{array}$ & $z r-16$ wt $\not 6 U$ & 39.0 & 9.2 & 51.8 & 37.9 & 5.1 & 56.9 \\
\hline
\end{tabular}

The converse possibility, that the $\epsilon$ phase alone was responsible for the loss, was investigated by reducing the concentration of uranium in the $\epsilon$ phase. Samples of $\mathrm{Zr}$ - low U alloy were heated to $500^{\circ} \mathrm{C}$ (the two-phase region) for one day to speed migration of uranium to the $\delta$ phase, and then were cooled slowly to prevent supersaturation of the $\epsilon$ phase. The equilibrium solubility of uranium in zirconium is low at room temperature, so that $99.5 \%$ of the uranium was precipitated as the $\delta$ phase(19). The alloy was electrolytically disintegrated in $10 \mathrm{M}$ $\mathrm{HNO}_{3}$. Although the uranium content of the $\mathrm{ZrO}_{2}$ sludge was high, it was lower than was found in the single-phase alloy. It can be concluded that the uranium in the sludge comes from both the $\delta$ and $\epsilon$ phases. A slightly higher percentage of the uranium from the homogeneous phase was retained by the siudge. 
The $\mathrm{ZrO}_{2}$ sludge from the disintegration of $\mathrm{Zr}$ - 10 wt \% U alloy was analyzed by X-ray diffraction. Heat treatment prior to electrolytic attack did not affect the X-ray diffraction analysis of the $\mathrm{ZrO}_{2}$. The analyses showed that most of the sludge was an amorphous form of $\mathrm{ZrO}_{2}$. An X-ray pattern was found that corresponded to a double oxide of zirconium and uranium(20). In some samples a pattern corresponding to zirconium carbide was present; the carbon comes from the graphite crucible in which the alloy was cast. Photomicrographs of the alloy showed zirconium carbide inclusions of 15 to 25 vol \%. Ignition in air made the $\mathrm{ZrO}_{2}$ more crystalline and decomposed the zirconium carbide. The double oxide was not affected.

\section{DISSOLUTION OF ALUMINUM IN NITRIC ACID}

Aluminum dissolves electrolytically in nitric acid at a rate of 0.37 g/amp-hr. The dissolution rate of the anode was not changed by variation in current density from 0.03 to $1.0 \mathrm{amp} / \mathrm{cm}^{2}$, in solution temperature from 25 to $108^{\circ} \mathrm{C}$, in aluminum concentration from 0 to $1 \mathrm{M}$, or in nitric acid concentration from 1.5 to $6 \mathrm{M}$. The observed rate is slightly higher than one would expect $(0.34 \mathrm{~g} / \mathrm{amp}-\mathrm{hr})$ if the only method of oxidation of aluminum to $\mathrm{Al}^{+3}$ were electrolytic. The increase is presumed to be caused by chemical attack on the anodic aluminum. Aluminum cathodes, as well as samples that are electrically "floating" in the solution, dissolve at a much slower rate that is proportional to the surface area exposed to the electrolyte. These pieces of aluminum undergo chemical attack only.

A mercury catalyst is used in the chemical dissolution of aluminum in a nitric acid system. Since the quantity of catalyst required for irradiated aluminum is high, the combination of electrolytic and chemical dissolution was investigated. The dissolution rate of an aluminum anode remained constant at $0.37 \mathrm{~g} / \mathrm{amp}-\mathrm{hr}$ when the $\mathrm{Hg}^{+2}$ concentration was varied from $1.6 \times 10^{-4}$ to $1.0 \times 10^{-3} \mathrm{M}$ in 1.5 to $6 \mathrm{M} \mathrm{HNO}_{3}$. The aluminum cathode dissolved at about twice the rate of a piece of aluminum suspended in the solution, probably because of a higher concentration of $\mathrm{Hg}^{+2}$ lons at the cathode than at the surface of the control plece. No measurements were made on irradiated aluminum and none of the samples were pretreated with mercury.

When 60-cps alternating current was applied to two aluminum electrodes, they both behaved anodically, and both electrodes dissolved at a rate of $0.37 \mathrm{~g} / \mathrm{amp}-\mathrm{hr}$. Apparently the frequent current reversals did not permit $\mathrm{Hg}^{+2}$ to penetrate the oxide coating.

Aluminum-clad Al - 16 wt $\%$ U alloy was dissolved electrolytically in both 4 and $10 \mathrm{M} \mathrm{HNO}_{3}$ without the addition of mercury catalyst. At a current density of $0.40 \mathrm{amp} / \mathrm{cm}^{2}$, the current utilizations were 0.48 and $0.45 \mathrm{~g}$ of cladding plus alloy per amp-hr, respectively. There was no undissolved residue. 


\section{DISINTEGRATION OF GRAPHITE-URANIUM FUEL IN NITRIC ACID}

An unirradiated fuel element consisting of graphite - 14 wt $\%$ was disintegrated electrolytically in bolling $10 \mathrm{M} \mathrm{HNO}_{3}$. Similar work has been previously reported ${ }^{(21)}$. The graphite sludge was leached for 3 hours in boiling IOM $\mathrm{HNO}_{3}$. The remalning sludge was found to contain $0.1 \%$ of the total uranium. The current utilization was $0.75 \mathrm{~g} / \mathrm{amp}-\mathrm{hr}$ at a density of $0.63 \mathrm{amp} / \mathrm{cm}^{2}$. The dissolver solution contained $99.8 \%$ of the uranium; the leach solution, $0.1 \%$; and the sludge, $0.1 \%$.

The graphite-uranium fuel specimens used in this study were prepared by mixing $\mathrm{UO}_{2}$ with graphite flour and a liquid resin binder, and graphitizing the mixture at $2400^{\circ} \mathrm{C}$. At this temperature the uranium is converted to $\mathrm{UC}_{2}$; however, the $\mathrm{UC}_{2}$ reacts rapidly w1th molsture and most of the uranium in the fuel was probably present as the oxide. No analysis was made to confirm this.

\section{CHEMICAL DISSOLUTION OF $\mathrm{UO}_{2}$ IN NITRIC ACID}

The chemical dissolution rate of sintered $\mathrm{UO}_{2}$ pellets was determined at $90^{\circ} \mathrm{C}$ and at the boiling point as a function of nitric acid concentration, both with and without dissolved stainless steel present. As stated previously, corrosion of an electrolytic dissolver made of stainless steel can be decreased to an acceptable rate by operating the dissolver at 85 to $90^{\circ} \mathrm{C}$. Decreasing the temperature from the bolling point to $85^{\circ} \mathrm{C}$ would have little effect on the electrolytic dissolution rate of stainless steel, Zircaloy, or aluminum claddings, but the rate of chemical dissolution of the $\mathrm{UO}_{2}$ thus exposed would be expected to decrease.

The pellets that were used for these tests were $3 / 8$ inch in diameter and $3 / 8$ inch high, and had been compacted to $92 \%$ of theoretical density before sintering. Since the instantaneous penetration rates increased as the pellets disintegrated, a mean rate was calculated from the original peliet radius and the time required for total dissolution of the pellet. These mean penetration rates for three concentrations of nitric acid at $90^{\circ} \mathrm{C}$ are given in Figure 4. Rates are also shown for similar solutions that contain about $12 \mathrm{~g} / \mathrm{l}$ of electrolytically dissolved stainless steel. The increase in rates shown is in accordance with the report that $\mathrm{Fe}^{+3}$ increases the dissolution rate of sintered $\mathrm{UO}_{2}$ in boiling nitric acid(22). No explanation is apparent for the fact that the rate at $90^{\circ} \mathrm{C}$ is faster than that at the boling point in $4 \mathrm{M} \mathrm{HNO}_{3}$. The width of the points (X-coordinate) indicates the range of acid concentration during the dissolution except for those solutions containing dissolved stainless steel. The acid-to- $\mathrm{UO}_{2}$ mole ratio was maintained high in order that the acid concentration would not change appreciably and affect the mean penetration rate. 


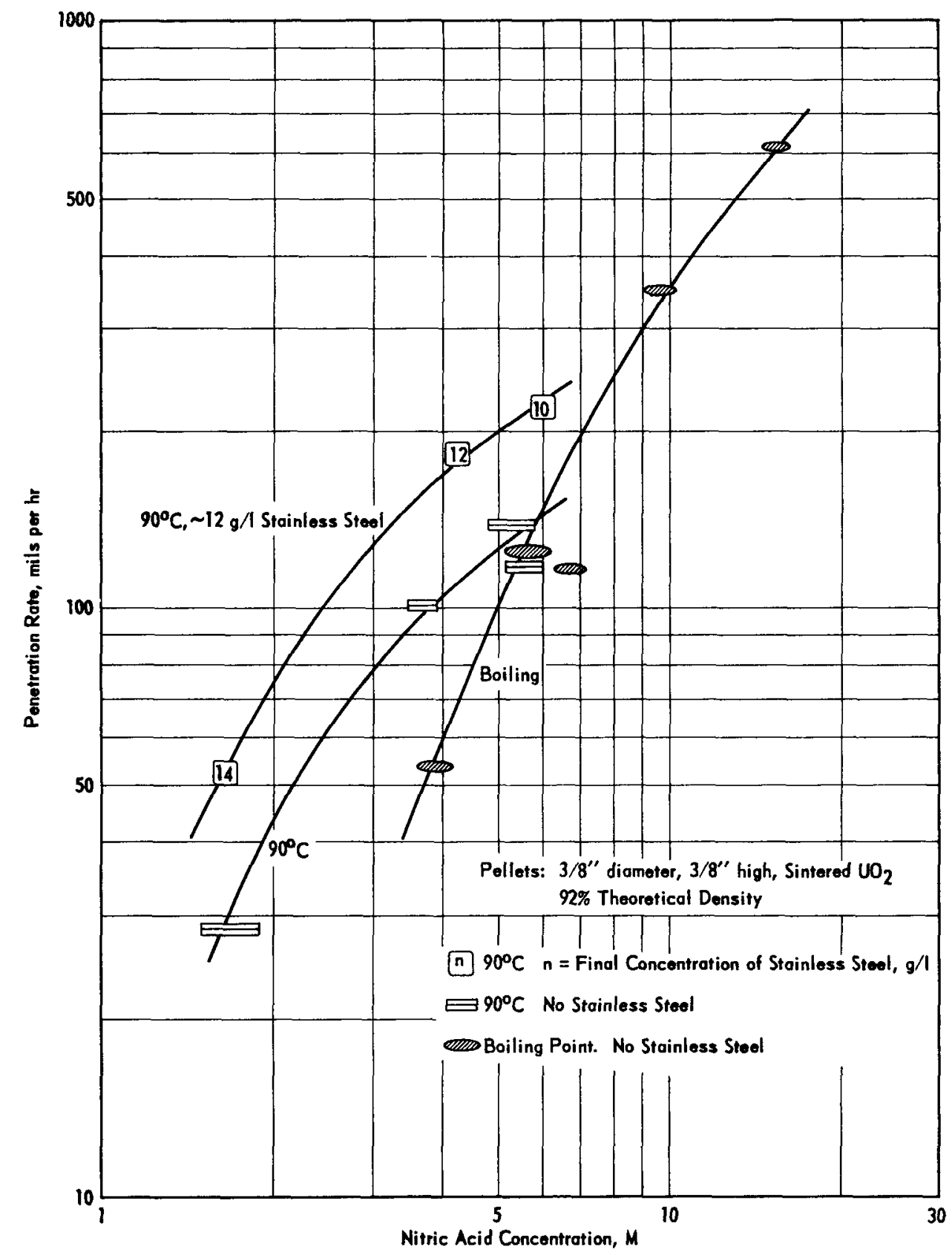

FIG. 4 MEAN PENETRATION RATE OF UO 2 PELLETS IN NITRIC ACID 


\section{GASES EVOLVED DURING ELECTROLYTIC DISSOLUTION IN NITRIC ACID}

Reduction at the tantalum or columbium cathode of an electrolytic cell containing nitric acid as the electrolyte occurs by five principal processes:

$$
\begin{aligned}
& \text { (1) } \mathrm{NO}_{3}^{-}+4 \mathrm{H}^{+}+3 \mathrm{e}^{-} \rightarrow \mathrm{NO}+2 \mathrm{H}_{2} \mathrm{O} \\
& \text { (2) } \mathrm{NO}_{3}^{-}+2 \mathrm{H}^{+}+\mathrm{e}^{-} \rightarrow \mathrm{NO}_{2}+\mathrm{H}_{2} \mathrm{O} \\
& \text { (3) } 2 \mathrm{NO}_{3}^{-}+1 \mathrm{H}^{+}+8 \mathrm{e}^{-} \rightarrow \mathrm{N}_{2} \mathrm{O}+5 \mathrm{H}_{2} \mathrm{O} \\
& \text { (4) } 2 \mathrm{NO}_{3}^{-}+12 \mathrm{H}^{+}+10 \mathrm{e}^{-} \rightarrow \mathrm{N}_{2}+6 \mathrm{H}_{2} \mathrm{O} \\
& \text { (5) } 2 \mathrm{H}^{+}+2 \mathrm{e}^{-} \rightarrow \mathrm{H}_{2}
\end{aligned}
$$

The solutions were not analyzed for ammonium ion, which is a remotely possible cathodic reduction product. Competition between reactions 1 through 4 for the reduction of nitrate ion is complex, and the quantities of the reduction product measured in the gas phase are a function of temperature and solubility in the electrolyte. The significant point that has been determined is that the formation of hydrogen (reaction 5) accounts for less than $2 \%$ of the total cathode gas. A typical composition is of the order of $0.3 \% \mathrm{H}_{2}$ for the period of dissolution. The percentage of hydrogen in the evolved gas may be slightly higher than this in the first stages of dissolution when the electrolyte is being saturated with oxides of nitrogen. Both tantalum and columbium are subject to deterioration by hydrogen embrittlement. The tantalum and columbium cathodes used for the laboratory work have not been so embrittled after over a year of service. This is perhaps the best indication of the minor contribution of hydrogen to the cathode gases. The quantities of gas liberated from a tantalum or columbium cathode in $10 \mathrm{M} \mathrm{HNO}_{3}$ varied from 30 to $150 \mathrm{cc} / \mathrm{amp}-\mathrm{hr}$ under a variety of conditions. Table VIII summarizes the composition of cathode gases at

\begin{tabular}{|c|c|c|c|}
\hline Cathode & Anode & $\begin{array}{l}\text { N1trogen Oxides } \\
\text { and } \mathrm{N}_{2}, \% \\
\end{array}$ & $\mathrm{H}_{2}, \not 6$ \\
\hline $\mathrm{Ta}$ & SS & 98.6 & 1.29 \\
\hline $\mathrm{Ta}$ & $\mathrm{Zr}$ & 99.5 & 0.51 \\
\hline $\mathrm{Ta}$ & Z1rcaloy-2 & $99 \cdot 9$ & 0.03 \\
\hline $\mathrm{Cb}$ & $\mathrm{Zr}$ & 98.9 & 1.17 \\
\hline $\mathrm{Cb}$ & SS & 99.6 & 0.24 \\
\hline $\mathrm{Cb}$ & Z1rcaloy-2 & 96.7 & 0.04 \\
\hline $\mathrm{Ta}$ & $\mathrm{Zr}$ & 99.7 & 0.28 \\
\hline $\mathrm{Cb}$ & $\mathrm{Al}$ & 99.9 & 0.05 \\
\hline $\mathrm{Ta}$ & Al & 99.9 & 0.03 \\
\hline $\mathrm{Cb}$ & $\mathrm{Zr}$ & 98.7 & 0.02 \\
\hline
\end{tabular}
$50^{\circ} \mathrm{C}$ in $10 \mathrm{M} \mathrm{HNO}_{3}$.

$$
\text { Table VIII }
$$

Cathode Gases Evolved During Electrolysis

$\begin{array}{ll}\text { Electrolyte: } & \quad 10 \mathrm{M} \mathrm{HNO}_{3} \\ \text { Temperature: } & 50^{\circ} \mathrm{C}\end{array}$


Only minor quantities of gases, in most cases immeasurably small amounts, are produced at stainless steel, zirconium, or aluminum anodes when these metals are dissolved electrolytically in 2 to $7 \mathrm{M} \mathrm{HNO}_{3}$. These gases are probably not electrolytic in origin but are due to chemical attack on these metals. During the electrolytic dissolution of stainless steel, oxygen will be produced at the anode if the acid is depleted below about 2M. A corresponding decrease in the utilization of current is observed (F1gure 2). Measurement and analysis of anode gas from a $1 \mathrm{M} \mathrm{HNO}_{3}$ electrolyte showed that the formation of oxygen accounted for $34 \%$ of the decrease in current utilization. Another side reaction is probably the oxidation of nitrite.

\section{ELECTROLYTIC PROPERTIES OF TANTALUM AND COLUMBIUM IN HIGH FIELDS OF RADIATION}

As previously discussed, both tantalum and columbium are characterized by abnormally high overvoltages that make them anodically inert during electrolytic dissolution in nitric acid. Thus, these metals are suitable materials of construction for a basket to contain the fuel to be dissolved, unless the high radiation fields anticipated in a plant dissolver significantly decrease this overvoltage. An electrolytic cell with both columblum and tantalum electrodes was suspended in a radiation field of $10^{7} \mathrm{rep} / \mathrm{hr}$. The electrodes of this cell were mounted in such a manner that the cell could be connected either with a tantalum anode and columbium cathode, or with a columbium anode and elther a tantalum or columbium cathode. The electrolyte was $10 \mathrm{M} \mathrm{HNO}_{3}$. A maximum of $18 \mathrm{v}$ was applied to the cell during the test.

When a potential of $18 \mathrm{v}$ was applied to the cell in the $10^{7}-\mathrm{rep} / \mathrm{hr}$ radiation field, a small diffusion current that decreased from $2 \mathrm{ma}$ to about $0.2 \mathrm{ma}$ was observed during a total exposure of $5 \times 10^{7} \mathrm{rep}$, even though no anodic dissolution or anodic oxygen was observed. The current then remained constant at 0.2 ma for exposure up to $10^{9}$ rep, at which point the test was terminated. A marked increase in current would have resulted if the overvoltages of tantalum or columbium had been decreased to less than $18 \mathrm{v}$.

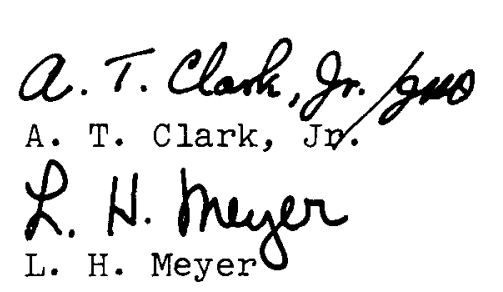

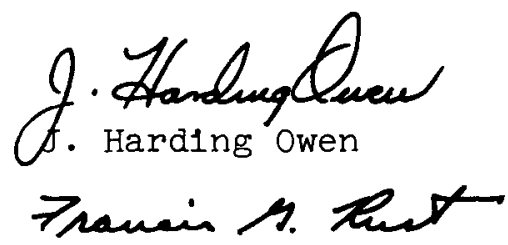

F. G. Rust

Separations Engineering Division 


\section{BIBLIOGRAPHY}

1. Proceedings of the AEC Symposium for Chemical Processing of Irradiated Fuels from Power, Test, and Research Reactors. Hanford Operations Office, Richland, Wash. AEC Research and Development Report TID-7583, 446 pp. (October 1959).

2. Smith, P. W. The Zirflex Process Terminal Development Report. General Electric Co., Hanford Atomic Products Operation, Richland, Washington. AEC Research and Development Report HW-65979, 51 pp. (August 1960).

3. Fisher, F. D. The Sulfex Process Terminal Development Report. General Electric Co., Hanford Atomic Products Operation, Richland, Washington. AEC Research and Development Report HW-66439, 29 pp. (August 1960).

4. Pitzer, E. C. Electrolytic Dissolution of Stainless Steel Clad Fuel Assemblies. General Electric Co., Knolls Atomic Power Laboratory, Schenectady, N. Y. AEC Research and Development Report KAPL-653, 35 pp. (December 1951).

5. Slansky, C. M., et al. Review of Research and Development at the Idaho Chemical Processing Plant on the Electrolytic Dissolution of Nuclear Fuel. Phlliips Petroleum Co., Idaho Falls, Idaho. AEC Research and Development Report IDO-14535, 57 pp. (February 1961).

6. Misch, R. D. and W. E. Ruther. "The Anodizing of Zirconium and Other Transition Metals in Nitric Acid". Journal of the Electrochemical Soclety 100, No. 12, 531-37 (1953).

7. Washburn, E. W., editor-in-chief. International Critical Tables of Numerical Data, Physics, Chemistry and Technology. Vol. VI. New York: McGraw-Hil1, p. 241 (1929).

8. Reprocessing of Power Reactor Fuels - Seventh Quarterly Progress Report - April 1 to July 1, 1959. Compiled by L. H. Meyer and E. S. Occhipinti. E. I. du Pont de Nemours \& Co., Savannah River Laboratory, A1ken, S. C. AEC Research and Development Report DP-421, $10 \mathrm{pp}$. (September 1959).

9. Reprocessing of Power Reactor Fuels - Eighth Quarterly Progress Report - July 1 to October 1, 1959. Complled by E. S. Occhipint1. E. I. du Pont de Nemours \& Co., Savannah River Laboratory, A1ken, S. C. AEC Research and Development Report DP-439, $10 \mathrm{pp.} \mathrm{(November}$ 1959). 
10. Reprocessing of Power Reactor Fuels - Ninth Quarterly Progress Report - October 1, 1959 to January 1, 1960. Compiled by L. H. Meyer. E. I. du Pont de Nemours \& Co., Savannah River Laboratory, Alken, S. C. AEC Research and Development Report DP-479, 11 pp. (March 1960).

11. Reprocessing of Power Reactor Fuels - Eleventh Quarterly Progress Report - January 1 to April 1, 1960. Complled by E. S. Occhipinti. E. I. du Pont de Nemours \& Co., Savannah River Laboratory, Aiken, S. C. AEC Research and Development Report DP-491, 14 pp. (October 1960).

12. Reprocessing of Power Reactor Fuels - Eleventh Quarterly Progress Report - April 1 to July 1, 1960. Compiled by L. H. Meyer. E. I. du Pont de Nemours \& Co., Savannah River Laboratory, Aiken, S. C. AEC Research and Development Report DP-519, 17 pp. (August 1960).

13. Reprocessing of Power Reactor Fuels - Twelfth Quarterly Progress Report - July 1 to October 1, 1960. Compiled by E. S. Occhipinti. E. I. du Pont de Nemours \& Co., Savannah River Laboratory, Aiken, S. C. AEC Research and Development Report DP-546, 8 pp. (January 1961).

14. Reprocessing of Power Reactor Fuels - Thirteenth Quarterly Progress Report - October 1, 1960 to January 1, 1961. Compiled by F. G. D. Rust. E. I. du Pont de Nemours \& Co., Savannah River Laboratory, Alken, S. C. AEC Research and Development Report DP-574, 14 pp. (April 1961).

15. Reprocessing of Power Reactor Fuels - Fourteenth Quarterly Progress Report - January 1 to April 1, 1961. Compiled by J. H. Owen. E. I. du Pont de Nemours \& Co., Savannah River Laboratory, Aiken, S. C. AEC Research and Development Report DP-588, 12 pp. (May 1961).

16. McIntosh, A. B. and T. E. Evans. "The Effect of Metal Species Present in Irradiated Fuel Elements on the Corrosion of Stainless Steel in N1tric Ac1d". Proc. U. N. Intern. Conf. Peaceful Uses Atomic Energy, 2nd, Geneva 17, 206-15 (1958). P/30

17. McIntosh, A. B., et al. The Effect of Dissolved Chromium on the Corrosion Rate of Two Chromium-Nickel - Austenitic Steels in Bolling Nitric Acid. Culcheth Labs., Culcheth Lancs, England. Risley $8012,28 \mathrm{pp}$. (November 1951).

18. Lustman, B. and F. Kerze, Jr. The Metallurgy of Zirconium. Ist Ed. New York: McGraw-Hill, pp. 663-5 (1955).

19. Saller, H. A. and F. A. Rough. Compilation of U. S. and U. K. Uranium and Thorium Constitutional Diagrams (First Edition). Battelle Memorial Institute, Columbus, Oh1o, AEC Research and Development Report BMI-1000, $141 \mathrm{pp}$. (June 1955). 
20. Larsen, R. P., et al. A Study of the Explosive Properties of Uranium-Zirconium Alloys. Argonne National Laboratory, Lemont, Ill. AEC Research and Development Report ANL-5135, 22 pp. (July 1954).

21. Fromm, L. W. Recovery of Uranium from Graphite Shapes by Electrolytic Graphite Disintegration in Nitric Acid. Oak Ridge National Laboratory, Tenn. AEC Research and Development Report ORNL-238, 25 pp. (February 1949) (declassified March 9, 1957).

22. Maness, R. F. Power Reactor Fuels Reprocessing Progress Report on Corrosion Studies. General Electric Co., Hanford Atomic Products Operation, Richland, Wash. AEC Research and Development Report HW-61662, 57 pp. (August 1959). 